KYIV-MOHYLA

HUMANiTIES JOURNAL

KYIV-MOHYLA SCHOLARLY PEER-REVIEWED JOURNALS

The German Topos of Ukraine as a Lost Homeland:

Ukrainian Topography in the Poem "Flight Into Kyiv" by Hans-Ulrich Treichel

Author(s): Ievgeniia Voloshchuk

Source: Kyiv-Mohyla Humanities Journal 5 (2018): 171-181

Published by: National University of Kyiv-Mohyla Academy

http://kmhj.ukma.edu.ua/ 


\title{
The German Topos of Ukraine as a Lost Homeland: Ukrainian Topography in the Poem "Flight Into Kyiv" by Hans-Ulrich Treichel ${ }^{1}$
}

\author{
Ievgeniia Voloshchuk \\ European University Viadrina, Frankfurt (Oder), \\ Axel Springer Endowed Chair for German-Jewish Literature and Cultural History, \\ Exile and Migration
}

\begin{abstract}
The article focuses on the cartographic enactment of the topos of Ukraine as a lost homeland in contemporary German literary discourse on migration, and in particular in the body of work that conveys the voices of the "second generation" - children of the German (post-)war migration. The article analyses by way of an illustrative example Hans-Ulrich Treichel's poem "Flight into Kyiv," in which we find reflected the autobiographical theme of the (re)construction of the lost homeland of his father, a Volyn German who fled to Germany during the Second World War to escape reprisals of the Soviet army. The main object of research are the mental maps of Ukrainian space, which largely define the way Ukraine is represented both in contemporary German social discourse and in modern German literature. A textual analysis of the poem allows us to discern how the resource of the Western European construct of Eastern Europe is instrumentalized and aesthetically arranged by German (post)migration perception to institutionalize the image of Ukraine as a "lost homeland."
\end{abstract}

Key Words: mental maps, construct of Eastern Europe, phantom borders, homeland, Ukraine.

\section{Introduction. Ukraine on the German Mental Map}

Where is Ukraine? This question, the title of a collection of humanities research published in Germany in 2009, articulates one of the central problems in German(-language) discourse on modern Ukraine, and together with it the imperative behind the contemporary re-mapping of Ukrainian space. ${ }^{2}$

This article has been written as part of the research project "Ukraine as a Palimpsest: GermanLanguage Literature and the Ukrainian World From the Second Half of the 19th century to the Present" ("Die Ukraine als Palimpsest: deutschsprachige Literatur und ukrainische Welt von der zweiten Hälfte des 19. Jahrhunderts bis in die Gegenwart"), supported by the Fritz Thyssen Foundation (Az.10.16.2.041 SL).

2 Cf. Steffen Höhne and Justus H. Ulbricht, eds., Wo liegt die Ukraine? Standortbestimmung einer europäischen Kultur (Weimar: Böhlau, 2009). 
This question can also be found in the chapter heading "Ukraine's Absence on the Horizon of its Contemporaries" in the book Decision in Kyiv. Ukrainian Lessons by German historian Karl Schlögel. ${ }^{3}$ In his analysis of how post-Soviet Ukraine is represented in German space, he states that, from the time of the political paradigm shift of 1989-1991 right up to the political upheavals sparked by the Euromaidan in 2013-2014, the German consciousness did not acknowledge a new Ukrainian state, instead perceiving the country through the cartographical template of its Soviet past as an outpost of Russia. According to Schlögel, however, we are dealing with a more longstanding and complex tradition of mental mapping, one that has been determined by the very history of Ukraine as a border country that over the centuries has been shown on the map as a territory of other states (including as the borderland of large empires). For this reason, the history of Ukraine has been absorbed into the history of other countries, leaving it in the German consciousness as a country without its own history or even its own geography in any recognized sense of the term. ${ }^{4}$

Leaving aside historical factors, however, the aforementioned tradition of mapping Ukraine as an "absent" country is rooted in the mental map of Eastern Europe itself. This map unites in a generalized way a whole conglomerate of countries into a single homogenized picture, on the basis of those common characteristics that the Western European consciousness ascribes to Eastern Europe, the former thereby isolating itself from the latter as something Other. Hence such key concepts as "backwardness," "barbarianism," "half-savage/half-cultured" ${ }^{5}$ etc., a vague or even simply non-existent differentiation of geographical, historical and cultural borders within that conglomerate, and finally the general utilization of the image of Eastern Europe to institutionalize Western European identity are applied to all countries on that map, Ukraine included. Just like the other countries on this mental map, Ukraine is identified with the image of a half-familiar yet half-alien, half-near yet half-distant Otherness that represents the whole of Eastern Europe. ${ }^{6}$ The actual Ukrainian topography on that map remains a white space.

At the same time, for German cultural discourse the concept of Ukrainian space represents a particular experience. We are talking here of the theme of Ukraine as a lost homeland, a topos with a rich tradition in German-language literature of mapping Ukrainian space from an "in-between," "migratory" position, in contrast to the boundary between what is "ours" and what is "theirs" established by the mental map. At the same time, the very task of (re)constructing the image of a lost homeland assumes the active application of cartographical tools. To remember a lost homeland is to retrospectively re-map it, with the help above all of mental maps, be they local ones (maps of the "little

3 Cf. Karl Schlögel, Entscheidung in Kiew. Ukrainische Lektionen (München: Hanser, 2015).

4 Schlögel, Entscheidung in Kiew, 53.

5 Larry Wolff, "Die Erfindung Osteuropas: Von Voltaire zu Voldemort," in Europa und die Grenzen im Kopf, eds. Dagmar Granshammer-Hohl, Karl Kaser and Robert Pichler (Klagenfurt:

Wieser, 2003), 23.

6 Wolff, "Die Erfindung Osteuropas," 24. 
motherland") or collective ones (maps of large regions). How do such maps function in the formation of the German image of Ukraine as a lost homeland? How do the individual and collective notions of Ukrainian space pertaining to such maps interact with one another? It is this aspect, which at the level of literary analysis reflects the central question of contemporary research into mental maps, that we will examine in this article, taking the example of a short, but in its own way extremely illustrative poem by contemporary German writer Hans-Ulrich Treichel. ${ }^{7}$

\section{The Topos of the Lost Homeland}

The topos of Ukraine as a lost homeland in German-language literature is associated principally with writers of Jewish descent who were born in the (erstwhile) Habsburg provinces of Halychyna (Galicia) and Bukovyna, then moved to other countries and were inspired by their own nostalgia for their birthplaces to create outstanding literary images that in their turn become significant landmarks on the contemporary German map of Ukraine. Many German readers "recognize" on this map not the big cities or major centers of Ukrainian culture, but rather the Brody of Joseph Roth, the Chernivtsi of Paul Celan and Rose Ausländer, the village of Verbivtsi in Kolomyia, birthplace of Alexandr Granach, or the village of Zabolotiv, which is also located in modern-day Ivano-Frankivsk oblast, and was once the native shtetl of Manès Sperber. In the writings of these authors, and of many others who left Ukrainian space during the epoch of the world wars, a lament can be discerned for those long lost enclaves of cultural polyphony, in which Jewish, German, Austrian, Ukrainian, Polish and other traditions formed together into a single ensemble.

However, in German language literature there exists another, altogether different tradition of mapping Ukraine as a lost homeland, and it is to be found in the writings of German-language authors whose family history is connected to Ukraine's German diaspora. ${ }^{8}$ For these inhabitants of German settlements, the Ukrainian land was a "second homeland," a "home away from home," their "own" enclave, set far from the

$7 \quad$ I will limit myself to quoting Frithjof Benjamin Schenk, who precisely formulates the principal question for culturological and historical research into mental maps in his analytical article "Mental Maps: the Cognitive Mapping of the Continent as an Object of Research of European History": "At the centre stands the question of how our pictures (of the world) mediated by our culture influence our own idea of space, and how the collectively shared representation of the world around us - whether real or imagined - reflexively influences the processes that shape cultural commonality and identity," see: Frithjof Benjamin Schenk, "Mental Maps: Die kognitive Kartierung des Kontinents als Forschungsgegenstand der europäischen Geschichte," Europäische Geschichte Online, accessed October 22, 2017, http://ieg-ego.eu/de/threads/ theorien-und-methoden/mental-maps/frithjof-benjamin-schenk-mental-maps-die-kognitivekartierung-des-kontinents-als-forschungsgegenstand-der-europaeischen-geschichte/. 
German mainland in the midst of a world that was at once exotic and quite often intimidating. There is an extensive resource of written memoirs on life in these German villages, in particular those located in Ukrainian Volyn (Volhynia), just as there are on the deprivations endured by the Volyn Germans during the time of the Russian revolutions and the world wars, although both themes are also addressed by authors of fiction.

The history and sufferings of the Volyn Germans hold a particularly personal significance for the renowned contemporary writer and literary critic Hans-Ulrich Treichel, for his father was a Volyn German. According to the explanation provided in the novel Anatolin (2008), during the Second World War Treichel's father moved to Poland, which was at that time occupied by the Nazis. Fearing persecution at the hands of the advancing Soviet army, he then fled to Germany with his young wife, a native of one of the German settlements located on Polish territory. Their traumatic experience of war and exodus, and the influence that this experience had on their family's subsequent history and their children's generation, are the central pillars of thought in Treichel's literary work.

In particular, this issue is central to the above-mentioned novel Anatolin, which narrates an autobiographical journey to Poland and Western Ukraine, the homeland of the protagonist's parents..$^{9}$ The course of this journey was determined by the "blank spots" of his domestic reminiscences. Since the protagonist's parents consequently refrained from commenting on their past, the focal character is able to collect only bits and pieces of information about their homeland. Therefore he conceives his journey as an attempt to fill in the gaps in his own family story with concrete images. From this point of view, the way to Volyn and, more specifically, to Bryshche, the home village of the protagonist's father, turns out to be the way to his father and to himself. It is worthy to note that, in the case of West Ukrainian towns such as Lviv and Brody, the protagonist confines himself to a quick tourist look and mostly feels indifferent toward those significant topoi of German cultural remembrance. For him, the chief attraction on the map of Ukraine is still Volynian Bryshche.

The topos of the lost homeland of the father can also be found in some other works by Treichel. Thus, it presents an illustrative image of the contemporary (re)mapping of Ukrainian space from the perspective of the (cultural) history of German migration.

Leonhard Kremring, Die Frauen von Janowka: Eine wolhynische Familiengeschichte (2010; The Women of Yanovka: A Volynian Family Story) by Helmut Exner and others. the goal of his then-planned journey to Western Ukraine, as well as its supposed route. Cf. "Man möchte Varianten des eigenen Lebens erzählt bekommen. Hans-Ulrich Treichel im Gespräch mit André Hille," Kulturmagazin Kulturstoff Heft 7 (2007), accessed August 9, 2018, http://www. poetenladen.de/andre-hille-hans-ulrich-treichel.htm. 


\section{Mapping the Phantom}

The phantom of his father's lost homeland takes centre stage in Treichel's poem "Flight into Kyiv" ("Anflug Kiew"), which was by the way included, together with writings by other authors, in the 2013 literary collection in the "Europa erlesen" series that was dedicated to Kyiv. Treichel's text, however, sits uncomfortably in this collection of texts because in his poem Kyiv is merely a toponym that lends impetus to the unfurling of the image of Ukraine as the lost homeland of the German diaspora.

I have set out the poem below in the original and in translation:

\section{Anflug Kiew}

Unter mir der Fluß

mit dem rollenden Namen, er rollte durch meine Kindheit, entsprang im Mund des Vaters, der das Schilf schnitt am Ufer, der den Stör fing, den Lachs, der den weißen ukrainischen Himmel mit schwäbischer Gründlichkeit pflügte, Schneisen schlug durch die Wildnis, nach zwei Kriegen noch immer herumtrug im Mund und unter der Zunge die Geräusche des Flusses, der noch immer den Pflug zog durch Nebel und Sumpf. ${ }^{10}$

\section{Flight to Kyiv}

Beneath me, the river with a rolling name, it rolled through my childhood, it sprang from the mouth of my father, who cut reeds on its banks, who fished for sturgeon, for salmon, who ploughed the white Ukrainian sky with Swabian thoroughness, cut firebreaks through thickets, and after two wars still carried in his mouth and under his tongue the river's rumble, who still dragged his plough 
through fog and swamp. ${ }^{11}$

In the poem, the image of Ukraine is to be found at the conjunction of "distant" and "close" perspectives. The former is indicated by the approach of the aircraft to the Kyiv intimated in the title, and the position of the lyrical hero surveying Ukrainian space from above through the aircraft window. But, notwithstanding the considerable viewing distance that enables him to take in the entire visible landscape, the gaze of the traveler selectively picks out just one topographical element — the river, whose "rolling name" ("der rollende Name"), he has known since childhood from stories told by his father:

Beneath me, the river
with a rolling name,
it rolled through my childhood,
it sprang from the mouth of my father.

In this way, Ukraine is depicted here as an almost unknown country, furnished with "traces" of family history that embellish it with the topoi of recollections and the migration experience of the author's "own" family history. Everything outside these topoi remains beyond the scope of the image, being "alien" or "unknown" space. In essence, what lies before us is a peculiar kind of contour map of Ukraine, one which visualizes - excepting the aforementioned topoi - Shlögel's thesis of "Ukraine's absence on the horizon of its contemporaries."

Another image of Ukraine can be seen in "close" perspective, represented in the poem by the figure of the lyrical hero's father. In the father's stories, Ukraine appears as a land that is familiar down to the last detail and "close"; it is depicted as a landscape filled with images, with sky, thickets, a reed-covered bank, and swamps. And the river itself, again never named, is shown on this picture as an absolutely "visible" topographical image of a river fabulously replete with fish. It is worth emphasizing that this picture takes form in the poem as a product of a great many intermediary stages: the lyrical hero paints precisely that image of Ukraine, which has lodged in his consciousness from his father's stories, stories which in turn reflect the image borne of retrospective reminiscence and the experience of migration. In this way, the writer puts a clear accent on the narrative nature of his father's depiction of Ukraine. The key role here is performed by the image of the river, construed simultaneously as a topographical element, as the current of the father's reminiscences of his Ukrainian past, and as a link in the chain between the father's stories of Ukraine and visual depictions of Ukraine.

In spite of the fact that the poem's text includes no detailed biography of the narrator's father, his Ukrainian past and with it Ukrainian space are given a fairly precise characterization. Formally, his Ukrainian past is described in terms of a patriarchal,

11 Here and later in the article, quotations from the poem are taken from both the translation and original set out above. 
bucolic life with its customary activities (chopping trees, working the land, fishing), and one that was, obviously, interrupted by wars. Accordingly, Ukrainian space is mapped as a patriarchal land of primeval nature far removed from western civilization, a land still untouched by modernity, where people earn their daily bread in simple, archaic ways, just as their ancestors did at the dawn of history. Meanwhile, the passing reference to the two wars, which in turn points to the upheavals in 2oth century Ukrainian history brought about by the world wars, introduces into an almost idyllic and largely ahistorical picture not only the glare of historical conflagrations, but also an intimation of the threats lurking in that space, indeed of its vulnerability to catastrophe. Such a picture of Ukrainian space replicates the model that lies at the heart of the Western European mental map of Eastern Europe.

The connection between Treichel's image of Ukraine and this model is further reinforced by the motif of the plough, which as the dominant image of the father's Ukrainian experience affirms the notion of exceptionally heavy labor and overcoming life's hardships. The image of the father ploughing the Ukrainian sky is, clearly, a lyrical paraphrase of the father's compulsive thought that living and working in Ukraine was like trying to plough the sky. This aspect of Treichel's image of Ukraine invokes the mental notions of the "backwardness" of Eastern Europe and its "being civilized" by Western Europe. This reference is denoted in the text by the imagologically loaded contrast between the "white Ukrainian sky" ("der weiße ukrainische Himmel") that is to be ploughed, and the "Swabian thoroughness" ("schwäbische Gründlichkeit"), with which the father works. ${ }^{12}$ This "thoroughness" (or "diligence"), manifested as a national characteristic, bears the mark of the civilizing progress of the German spirit over as yet untamed white (barren, empty, "virgin") Ukrainian space. This semantic shows itself still more clearly in the image of the father clearing firebreaks in the Ukrainian thickets ("der ... Schneisen schlug durch die Wildnis"), thereby carrying out not only pragmatic peasant labor, but also fulfilling a civilizing function. This function, taken in combination with the latent juxtaposition of Swabian "thoroughness" and Ukrainian "laziness" or "carelessness," is the principal imagological marker for the father's "Germanness," which differentiates him from the aboriginal population and segregates him from Ukrainian space as from not his "own" territory. Moreover, the imagological (self-)portrait of the father is augmented by one more vital detail: the one thing missing from the whimsical combination of the plough/ploughing with atypical elements of the landscape (sky, fog, swamp) is the very land which the plough is supposed to till. Behind this paradoxical exception lies the diasporic sensation of the absence of terra firma beneath your feet, of a lack of sureness in the land on which you may live, but on which you cannot rely because it is not entirely "yours." It is no accident that the

12 The significance of imagological stereotypes in Treichel's work and their interconnection with the migration background of his family are studied thoroughly using the example of the image of the Pole in Jürgen Joachimsthaler's article: Jürgen Joachimsthaler, “Der Pole' sieht Polen. Hans-Ulrich Treichel in Lublin," Germano-Slavica. A Canadian Journal of Germanic and Slavic Comparative and Interdisciplinary Studies 12.1 (2000): 51-65. 
poem ends with the image of a swamp shrouded in fog, a metaphor for the fragility, the elusiveness, and the insecurity of one's homeland - a metaphor, in fact, for the memory's image of a lost homeland.

\section{Conclusion}

As a result of the layering of "close" and "distant" mapping perspectives, the image of Ukraine is itself multi-layered and full of contrasts, reflecting the various levels of its perception as space that is "half-mine" and "half-not-mine." Explicitly, such an outcome is found within the poem on the direct (the father's viewpoint) and the indirect (the son's viewpoint) experiences of migration. On one hand, this experience reduces Ukrainian space to the rudiments of a former half-home/half-not that lives on only in memories, the remainder of Ukrainian space that is irrelevant to reminiscences being excised from the image as "invisible" and "unknown." On the other hand, the migration experience of the father, as someone who both before and after his exodus feels rooted in Ukrainian and the German space alike, shapes Ukraine as a point of intersection for Ukrainian and German history. What is more, the connection between them is reinforced by shared historical traumas - the two world wars that unite these two spaces in the migrational discourse of memory (as the "common" setting for the experience of war), yet at the same time divide them (as events that shattered the conventional parameters of diasporic life and, in the final analysis, brought about the migrational schism in the family's diasporic story). The son feels that he has inherited and become part of this tortuous story - as a German born in post-war Germany and experiencing the pull of his father's former "homeland": distant, almost completely unknown and yet not entirely "alien." In this context, Treichel's image of Ukraine re-actualizes the map of phantom borders of former German settlements on the territory of modern-day Ukraine, and through this map inscribes the lyrical hero's family story into the wider history of Germany and Ukraine. ${ }^{13}$

At the same time, the image of Ukraine implicitly takes shape in the poem on the basis of the Western European mental map of Eastern Europe. It is significant that a number of modes of the cultural perception of Ukraine or Eastern Europe as a "half-own"/"half-alien" territory are reflected in the mapping strategies used by both the father and the son. In the father's reminiscences, imagologically determined first by his "diaspora," and then from the "migration" standpoint, the defining role is played by the concept of "not-quite-civilized" space, essential for the elaboration of "western" identity. This concept is identifiable in the image of patriarchal, bucolic Ukraine, a land

13 According to the theory jointly developed by Hannes Grandits, Béatrice von Hirschhausen, Claudia Kraft, Dietmar Müller and Thomas Serrier, phantom borders are "erstwhile, mainly political or territorial boundary definitions, which continue to structure space after they have been abolished." See: Béatrice von Hirschhausen et al., "Phantomgrenzen im östlichen Europa. Eine wissenschaftliche Positionierung," in Phantomgrenzen. Räume und Akteure in der Zeit neu denken, ed. Béatrice von Hirschhausen et al. (Göttingen: Wallstein, 2015), 18. 
where the father not only labored and struggled with primal nature, but also fulfilled a certain civilizing function, thereby affirming himself as a Swabian, a German, an "outsider" arrived from the West. As to the son's impressions of Ukraine - they employ artistic tools that emphasize "invisibility" and geographical blankness in the image of Ukraine. This effect is created at the beginning of the poem together with the "contour map" that the lyrical hero "sees" from the aircraft window, and is further strengthened at the end with the images of fog and swamp.

Within the interaction of these two versions of the image of Ukraine a bipolarity arises in the category of the "emptiness" that is employed in the Eastern European construct. This category is present in the metaphor of the "blank canvas," which Larry Wolff borrows from the travel writings of French historian Louis-Philippe de Ségur and turns into a paradigmatic exemplar to describe the "fantasies" of Eastern Europe that were borne of the Western European consciousness. The "blank canvas" is the place onto which Western Europe paints the European East, which must be assimilated and conquered. ${ }^{14}$ In Treichel's poem, the "white Ukrainian sky" to be worked by the father's plough provides a variation on this metaphor. However, when demonstrating in his article "The invention of Europe: from Voltaire to Voldemort" how a construct invented several centuries previously continued to function in the collective imaginings of Western Europe about Eastern Europe to this day, Larry Wolff quotes an observation by contemporary Croatian writer Dubravka Ugrešić to link the category of "emptiness" with that "absence" of representable space on the mental map that is best captured by the topographical metaphor of "white space":

Dubravka Ugrešić,- - writes Wolff, — observed that the cartological definition of Eastern Europe presented the same problem as before: "Many people in the West picture Eastern Europe as an empty space. It begins somewhere beyond the Iron Curtain, somewhere on the other side of the Wall, even now, when neither Curtain nor Wall still exist." 15

The contour map of Ukraine that Treichel's lyrical hero draws on his descent towards Kyiv, a map containing nothing except for the unnamed river, is a vivid illustration of the concept of "empty space" typical of the mental map of Eastern Europe that Ugrešić describes. The foregoing cartographical perspectives come together in the concept cast by Treichel's depiction of Ukrainian space as "virgin land," which is associated at once with nature "untamed" by civilization, and "white space" on the map.

And finally: not only can the contemporary map of Ukraine be reconstructed from the poem, but also the mapping process itself, which is dramatized as an attempt at a new cultural assimilation of the father's lost homeland. At the same time, the direct, personal impressions of the lyrical hero align themselves around the maps that he has 
already inherited from "others": the "local" mental map of the father's "little homeland," the maps of phantom borders of the East European German diaspora, and the Western European mental map of Eastern Europe. It is in this stress field between reminiscence and invention that the contemporary German image of Ukraine arises, an image that Schlögel succinctly defines with the formula "Ukraine: so far, yet so near." 16

\section{Bibliography}

Joachimsthaler, Jürgen. "'Der Pole' sieht Polen. Hans-Ulrich Treichel in Lublin." Germano-Slavica. A Canadian Journal of Germanic and Slavic Comparative and Interdisciplinary Studies 12.1 (2000): 51-65.

Hirschhausen, Béatrice von, Grandits, Hannes, Kraft, Claudia et al. "Phantomgrenzen im östlichen Europa. Eine wissenschaftliche Positionierung.” In Phantomgrenzen. Räume und Akteure in der Zeit neu denken, edited by Béatrice von Hirschhausen, Hannes Granditset al., 13-56. Göttingen: Wallstein, 2015.

Höhne, Steffen, and Justus H. Ulbricht, eds. Wo liegt die Ukraine? Standortbestimmung einer europäischen Kultur. Weimar: Böhlau, 2009.

Schenk, Frithjof Benjamin. "Mental Maps: Die kognitive Kartierung des Kontinents als Forschungsgegenstand der europäischen Geschichte.” Europäische Geschichte Online. Accessed October 22, 2017. http://ieg-ego.eu/de/threads/theorien-undmethoden/mental-maps/frithjof-benjamin-schenk-mental-maps-die-kognitivekartierung-des-kontinents-als-forschungsgegenstand-der-europaeischengeschichte/.

Schenk, Frithjof Benjamin. "Mental Maps. Die Konstruktion von geographischen Räumen in Europa seit der Aufklärung." In Geschichte und Gesellschaft 28.3 (2002): 493-514.

Schlögel, Karl. Entscheidung in Kiew. Ukrainische Lektionen. München: Hanser, 2015. Schlögel, Karl. Im Raume lesen wir die Zeit. Über Zivilisationsgeschichte und Geopolitik. München; Wien: Hanser, 2003.

Treichel, Hans-Ulrich. "Anflug Kiew." In Europa erlesen: Kiew/Kyiv, edited by Olena Nowikowa and Ulrich Schweier, 197. Klagenfurt; Celovec: Wieser, 2013.

Wolff, Larry. "Die Erfindung Osteuropas: Von Voltaire zu Voldemort." In Europa und die Grenzen im Kopf, edited by Dagmar Granshammer-Hohl, Karl Kaser and Robert Pichler, 21-34. Klagenfurt: Wieser, 2003.

Wolff, Larry. Inventing Eastern Europe: The Map of Civilization on the Mind of the Enlightenment. Stanford: Stanford University Press, 1994. 
IEVGENIIA VolOSHCHUK. The German Topos of Ukraine as a Lost Homeland:

Prof. Dr. Ievgeniia Voloshchuk obtained her PhD in 1994 with a thesis on Kafka and qualified as a professor in 2009 with a dissertation about the intellectual and aesthetic tendencies of German-language modernist literature in the works of Rainer Maria Rilke, Thomas Mann, and Max Frisch. Between 2003 and 2016 she worked at the Shevchenko Institute of Literature of the National Academy of Sciences of Ukraine (Kyiv). Currently, Prof. Voloshchuk is an academic fellow at the Axel Springer Endowed Chair for GermanJewish Literature and Cultural History, Exile and Migration (European University Viadrina, Frankfurt/Oder). 